\title{
METODE SUGESTI-IMAJINASI DALAM PEMBELAJARAN MENULIS DENGAN MEDIA LAGU
}

\author{
OLEH: \\ NURSYAIDAH ${ }^{1}$
}

\begin{abstract}
Imagination-suggestion method is a technique in writing lesson by using a song. Basically, this method is used by giving suggestions to stimulate the student's imagination. The learning activities are divided into three stages:(1) planning, (2) activities, and (3) evaluating. The three stages in the activities are done by teacher and students before, during, and after leaning process. The application of this method inteachine descrintive writing can immnve the or remembering and organizing the facts, and giving the responds in theverbal symboland (4) the ability to make sentence variations.
\end{abstract}

Keyword: Method, Suggestion, Imagination

\section{PENDAHULUAN}

Menulis merupakan salah satu keterampilan berbahasa yang dibutuhkan untuk meningkatkan kualitas pembelajaran. Dengan penguasaan keterampilan menulis, diharapkan siswa dapat mengungkapkan gagasan, pikiran, dan perasaan yang dimilikinya setelah menjalani proses pembelajaran dalam berbagai jenis tulisan, baik fiksi maupun nonfiksi ${ }^{2}$. Asumsinya, pengungkapan tersebut merupakan manifestasi peresapan, pemahaman, dan tanggapan siswa terhadap berbagai hal yang diperolehnya dalam proses pembelajaran. Dengan demikian, segala informasi, ilmu pengetahuan, dan berbagai kecakapan yang diperoleh siswa dalam pembelajaran tidak akan sekadar menjadi hafalan yang mudah dilupakan sesaat selah siswa menjalani tes.

Dilihat dan segi pragmatiknya, keterampilan menulis dibutuhkan diberbagai jenjang pendidikan, mulai dari sekolah dasar sampai perguruan tinggi. Meskipun demikian, pembelajaran menulis telah lama menjadi satu masalah dalam sistem pembelajaran bahasa Indonesia. Beberapa faktor yang oleh kebanyakan pengajar dianggap memberikan andil terhadap tidak tercapainya tujuan pembelajaran menulis adalah 1) rendahnya tingkat penguasaan kosa kata sebagai akibat rendahnya mimat baca, 2) kurangnya penguasaan keterampilan mikrobahasa, seperti penggunaan tanda bahasa, kaidah-kaidah penulisan, penggunaan kelompok kata, penyusunan klausa dan kalimat dengan struktur yang benar, sampai penyusunan paragraf, 3) kesulitan

\footnotetext{
${ }^{1}$ Penulis adalah Dosen PGMI Fakultas Tarbiyah dan Ilmu Keguruan IAIN Padangsidimpuan

${ }^{2}$ Keraf, Gorys, Komposisi: Sebuah pengantar kemahiran bahasa.(Flores: Nusa Indah, (1994) h. 12

Metode Sugesti Nursyaidah 
menemukan metode pembelajaran menulis yang sesuai dengan kondisi dan kemampuan siswa, serta 4) ketiadaan atau keterbatasan media pembelajaran menulis yang efektif ${ }^{3}$.

Semua permasalahan tersebut akhirnya menjadi seperti benang kusut yang sulit diuraikan. Dibutuhkan sistem pembelajaran bahasa Indonesia yang benar-benar bisa mengakumulasi semua permasalahan itu dan sekaligus menemukan solusi yang menyelureh dan mengakar pada permasalaban yang ada. Adanya ketentuan mengenai jenis dan jumlab buku yang harus dibaca siswa pada setiap semester, pembuatan sistem penilaian yang akurat bagi pencapaian standar kompetensi mata pelajaran bahasa Indonesia, uji ilmiah dan pelatihan penggunaan berbagal metode pembelajaran bahasa Indonesia, serta tawaran alternatif media pembelajaran bahasa Indonesia dapat menjadi solusi bagi berbagai masalah pembelajaran bahasa Indonesia. Mengenai tawaran alternatif media pembelajaran bahasa Indonesia, lagu dapat dieksploitasi untuk membantu peningkatan kemampuan menulis.Dengan metode sugesti-imajinasi, lagu tidak banya digunakan untuk menciptakan suasana yang nyaman tetapi juga memberikan sugesti yang merangsang berkembangnya imajinasi siswa.

Metode Sugesti-Imajinasi.

Pada prinsipnya, metode sugesti-imajinasi adalah metode pembelajaran menulis dengan cara memberikan sugesti lewat lagu untuk merangsang imajinasi siswa. Dalam hal ini, lagu digunakan sebagai pencipta suasana sugestif, stimulus, dan sekaligus menjadi jembatan bagi siswa untuk membayangkan atau menciptakan gambaran dan kejadian berdasarkan tema lagu.Respons yang diharapkan muncul dan para siswa berupa kemampuan melihat gambaran-gambaran kejadian tersebut dengan imajinasiimajinasi dan logika yang dimiliki lalu mengungkapkan kembali dengan menggunakan simbol-simbol verbal.

Sebagaimana diungkapkan oleh Bobbi Dc Porter dan Mike Hernacki dalam bukunya yang berjudul Quantum Learning, menulis adalah aktivitas seluruh otak yang menggunakan belahan otak kanan (emosional) dan belahan otak kiri (logika) dan tak satapun belahan otak itu bekerja secara sempurna tanpa adanya rangsangan atau dorongan dan bagian yang lain ${ }^{4}$. Penggunaan metode sugesti-imajinasi dapat mengoptimalkan kerja belahan otak kanan sehingga para siswa dapat mengembangkan imajinasinya secara leluasa. Efek positif dan optimalisasi kerja belahan otak kanan adalah rangsangan atnu dorongan bagi kerja belahan otak kin sehingga pada saat yang bersamaan pam siswa juga dapat mengembangkan logikanya.Keseimbangan kinerja otak kanan dan kiri ini diharapkan dapat meningkatkan kemampuan siswa dalam perolehan informasi, pengorganisasian informasi, pembuatan outline, dan akhimya menuliskan informasi tersebut dalam bentuk tulisan atau karangan yang baik.

\footnotetext{
${ }^{3}$ Gorys, Komposisi..., h. 13 .

${ }^{4}$ De Porter, Bobbi and Mike Hernacki, Quantum learning: Unleashing the genius in you, atau Quantum learning: Membiasakan belajar nyaman dan menyenangkan, terjemahan Alwiyah Abdurrabman. (Bandung: Kaifa. 1999) h. 122

Metode Sugesti. Nursyaidah 


\section{PEMBAHASAN DAN ANALISIS}

\section{A. Penerapan Metode Sugesti-Imajinasi}

Penggunaan metode sugesti-imajinasi dalam pembelajaran menulis dibagi menjadi tiga tahap utama. Ketiga tahap tersebut pada dasarnya memupakan kegiatan yang ditempuh oleh guru dan siswa pada saat sebelum, selama, dan sesudah pembelajaran.Ketiga tahap yang dimaksud adalab 1) perencanaan, 2) pelaksanaan, dan 3) evaluasi ${ }^{5}$.

Pada tahap perencanaan, ada tiga kegiatan prapembelajaran yang harus dilakukan guru.Pertama, penelaahan materi pembelajaran.Kedua, pemilihan lagu sebagai media pembelajaran.Ketiga, penyusunan ancangan pembelajaran. Penelaahan materi perlu dilakaukan agar guru-guru benar-benar menguasai materi yang akan disampaikan dalam proses pembelajaran di kelas. Penguasaan teknik-teknik menulis, pemilihan tema, dan prioritas jenis tulisan atau karangan yang akan dibelajarkan menjadi poin-poin yang harus dicapai dalam kegiatan ini.

Penguasaan materi pembelajaran oleh guru tidak menjamin tercapainya tujuan pembelajaran. Lagu sebagai media juga sangat rnenentukan berhasil atau tidaknya proses pembelajaran tersebut. Pada kegiatan ini, guru harus benar-benar dapat memilih lagu yang tidak hanya sesuai dengan tema dan materi pembelajaran tetapi juga sesuai dengan "selera" dan minat para siswa. Lagu yang sesuai dengan tema dan materi pembelajaran tetapi tidak menarik bagi para siswa hanya akan menciptakan suasana yang tidak menyenengkan dan bahkan merusak suasana hati pam siswa. Hal ini sangat bertentangan dengan prinsip metode sugesti-imajinasi yang menghendaki terciptanya suasana nyaman dan menyenangkan sehingga para siswa tersugesti dan dapat mengembangkan imajinasi serta logikanya dengan baik.

Kegiatan menyusun ancangan pembelajaran merupakan langkah lanjutan yang ditempuh guru untuk memastikan bahwa proses pembelajaran yang akan dilaksanakan dapat berlangsung dengan baik. Ancangan pembelajaran hendaknya mencakup perumusan materi, tujuan, peudekatan, metode, media, dan evaluasi pembelajaran. Keberhasilan pelaksanaan kegiatan pada tahap pertama akan diuji pada tahap kedua, yalta tahap pélaksanaan. Mengacu pada yang telah dilakukan pada tahap pertama, proses pembelajaran menulis dengan metode sugesti imajinasi dibagi menjadi enam langkah. Berikut ini penjabaran mengenai enam langkah tersebut.

\section{Pretes}

Untuk mengukur kemampuan atau pengetahuan yang dimiliki siswa, terutama yang berkaitan langsung dengan keterampilan menulis, guru wajib memberikan pretes. Soal pretes hendaknya berupa perintah untuk membuat karangan atau tulisan. Jenis dan tema karangan harus disesuakan dengan materi pembelajaran yang akan

\footnotetext{
${ }^{5}$ Ginting,Vera, Penguatan Membaca, fasilitas sekolah dan keterampilan dasar membaca serta minat baca murid. irtike1 dalam Jurnal Pendidikan Penabur, No.O4fIV/Juli 2005
}

Metode Sugesti. Nursyaidah 
dilaksanakan. Disamping itu, pretes ini haruss memuat semua aspek yang diperlukan dalam menulis.

\section{Penyampaian tujuan pembelajaran}

Penting artinya bagi siswa untuk mengetahui tujuan pembelajaran yang akan dijalaninya dan kompetensi dasar yang hams dikuasal setelah proses pembelajaran dilaksanakan. Jika diibaratkan orang yang sedang menempuh perjalanan, keyakinan akan arah dan tujuan akan membuat orang tersebut tidak setengah hati dalam menempuh perjalanan tersebut. Demikian halnya dengan para siswa. Dengan mengetahui tujuan pembelajaran yang akan dilaksanakan, diharapkan siswa lebih siap dalam proses pembelajran tanpa takut, canggung, dan tertekan.

\section{Apresiasi}

Prinsip utama apersepsi adalah menjelaskan hubungan antara materi yang telah diajarkan dengan materi yang akan diajarkan. Guru dapat memberi ulasan singkat tentang materi pembelajaran kosa kata, kaidah-kaidah penulisan atau EYD, penyusunan klausa, pembuatan kalimat, dan penulisan paragraf. Kegiatan ini dapat menggugah kembali ingatan siswa terhadap materi-materi yang diperlukan dan sudah harus dikuasai siswa sebagai syarat dalam pembelajaran mënulis.

\section{Penjelasan praktik pembelajaran dengan media lagu}

Guru menjelaskan kepada siswa enam kegiatan yang akan merekajalani dalam proses pembelajaran. Keenam kegiatan tersebut adalah a) pemutaran lagu, b) penulisan gagasan yang muncul saat menikmati lagu dan sesudahnya, c) pengendapan atau penelaahan dan pengelompokan gagasan, d) penyusunan outline (kerangka karangan), e) penyusunan karangan, dan f) penilaian kelompok.

\section{Praktik pembe1ajaran}

Guru dan siswa aktif dalam kegiatan pembelajiran. Dälam proses ini guru haru dapat menjadi motivator dan fasilitator yang baik.

\section{Pasca tes}

Siswa menulis sebuah karangan tanpa didahulüi dengan kegiatan mendengarkan lagu. Jenis dan tema karangan tetap sama dengan materi pembelajaran yang bani saja dilaksanakan.

Evaluasi terhadap pelaksanaan dan pencapaian tujuan pembelajaran, menulis dengan metode sugesti-imajinasi menjadi tahap ketiga dan kegiatan pembelajaran tersebut. Dalam tahap ini, guru harus bisa melihat keberhasilan dan kekurangan yang teijadi selama proses pembelajaran berlangsung. Di sisi lain, membandingkan hasil pretes dan pascates dengan membuat grafik perolehan nilai dapat menjadi sarana yang cukup efektif untuk melihat persentase pencapaian tujuan pembelajaran yang telah dilaksanakan. 
Selain tiga tahap yang bersifat teknis, pembelajaran menulis dengan metode sugesti-imajinasi juga mensyaratkan beberapa hal yang bersifat normatif. Pertama, guru hárus mempunyai pengetahuan yang luas, terutama tentang lagu-lagu yang sedang digemari para siswa. Hal ini akan sangat membañtu guru dalam memilih lagu sebagai media. "Tabungan" pengetahuan itu juga dapat mendukung penampilan guru pada saat memberi arahan cara "mengeksploitasi" lagu untuk membangun imajinasi dan memunculkan gagasan-gagasan yang terpendam. Kedua, guru harus mampu mengolah emosi para siswa sehingga mereka benar-benar bisa menikmati lagu, bukan sekadar mendengarkan. Ketiga, guru harus bisa membangun relasi pertemanan.

Penerapan Metode Sugesti-Imajinasi dalam membelajaran menulis deskripsi adalah untuk memberikan gambaran yang lebih jelas, berikut dipaparkan sebuah model penggunaan metode sugesti-imájinasi dengàn media lagu dalam pembelajaran menulis ${ }^{6}$.

\section{B. Tahap Perencanaan}

Tahap perencanaan mencakup penelaahan materi, pemilihan lagu, dan pembuatan ancangan pembelajaran. Masing-masing kegiatan terkait dengan pembelajaran menulis yang uraiannya adalah sebagal berikut:

1. Penelaahan materi
a. Pengertian karangan
b. Jenis-jenis karangan
c. Pengertian karangan deskripsi
d. Langkah-langkah menyusun karangan

2. Pemilihan lagu
a. Judul lagu : Yogyakarta
b. Penyanyi Kia Project
c. Pencipta : Adi/Katon

Lagu Yogyakarta sangat sesuai digunakan sebagai media pembelajaran menulis deskripsi dengan tema pariwisata. Deskripsi kota Yogyakarta dalam lagu tersebut dapat dieksploitasi untuk menggugah imajinasi siswa dan membangun opini-opini barn mengenai sebuah kota wisata. Berikut syair lagu ;

\section{Yogyakarta}

Pulangkekotamu

Ada setangkup

Haru dalam rindu

Masihh seperti dulu tiap sudut

Menyapaku bersahabat

Penuh selaksa makna

Terhanyut aku akan nostalgia

6Rabman, H, Eksploitasi potensi gambar dalam meningkatkan kemampuan menulis kalimat”. (Bandun\&: Ikatan Alumni FPBS dan Prodi Pengajaran Bahasa Indonesia Program Pascasarjana UPI (makalah, tidak diterbitkan 2005), h. 35

Metode Sugesti.... Nursyaidah 
Saat kita sering luangkan waktu

Nikmati bersama suasana Jogja

Di persimpangan langkahku terhenti

Ramai kaki lima, menjajakan

Sajian khas berselera orang

Duduk bersila

Musisi jalanan mulai beraksi

Seiring laraku kehilanganmu

Merintih sendiri, ditelan deru

Kotamu

Walau kini kau t'lah tiada, tak kembali

Namun kotamu hadirkan

Senyuminu abadi

Izinkanlah aku untuk slalu

Pulang lagi bila hati mulai sepi

Tanpa terobati

\section{Ancangan Pembelajaran}

1. Materi pembelajaran

a. Karangan adalah wacana tulis yang memiliki sebuah tema atau masalah dan harus memenuhi syarat-syarat tertentu. Wacana tulis tersebut berupa artikel, berita, cerita, laporan, dan sebagainya.

b. Ada lima jenis karangan, yaitu narai, deskripsi, eksposisi, argumentasi, dan persuasi.

c. Karangan deskripsi adalah tulisan yang bertujuan rnenggambarkan atau melukiskan sesuatu. Tulisan deskripsi bisa berupa karyafiksi atau nonfiksi.

d. Langkah-iangkah menyusun karangan deskripsi

1) Menentukan tema atau topik

Dalam karangan nonfiksi topik pada umumnya menjadijudul karangan karena topik merupakan pokok pikiran yang menjiwai seluruhkarangan.Pengambilan topik sebagai judul harus mempertimbangkan kesesuaiannya dengan jenis karangan.

2) Memahami tujuan karangan

Tujuan yang hendak dicapai menentukan arah, isi, dan jenis karangan. Karena karangan deskripsi bertujuan menggambarkan atau melukiskan sesuatu, arah dan isi karangan hendaknya bisa membawa pembaca pada sasaran tersebut.

3) Mengumpulan bahan

Bahan penulisan karangan deskripsi bisa diperoleh melalui kegiatan mengamati, berimajinasi, atau menggali pengalaman. 
4) Menelaah bahan

Telaah bahan meliputi kegiatan menilai, membandingkan, memilih, dan mengolah bahan sehingga susunan dan alur penelaahannya baik.

5) Menyusun kerangka karangan

Kerangka karangan adalah susunan pikiran utama yang telah diorganisasikan dan direalisasikan dalam kalimat-kalimat utaina.Kerangka karangan terdiri atas tiga bagian, yaitu pembukaan, isi, dan penutup.

6) Mengembangkan kerangka karangan menjadi karangan yang utuh dan padu.

2. Tujuan pembelajaran

a. Tujuan umum

Siswa dapat menulis secara efektif dan efisien berbagai jeniskarangan dalam berbagai konteks.

b. Kompetensi dasar

Siswa dapat menunjukkan karakteristik karangan deskripsi.

1) Siswa dapat mendaftar topik-topik yang dapat dikembangkan menjadi karangan deskripsi.

2) Siswa dapat menyusun paragraf deskripsi tentang benda, manusia atau suatu keadaan berdasarkan pengamatan,pendengaran, dan imajinasi.

3) Siswa dapat menyusun karangan deskripsi berdasarkan tema atau topik tertentu.

4) Siswa dapat menyunting karangan deskripsi yang ditulis temannya.

c. Pendekatan

Pendekatan yang akan digunakan dalam pembelajaran adalah pendekatan keterampilan proses dengan mengutamakan keaktifan dan pihak siswa.

d. Metode

Metode sugesti-imajinasi dilaksanakan secara "luwes" sesuai dengan kondisi dan keadaan siswa di setiap kelasnya.

e. Media

Lagu akan digunakan sebagai media dalam pembelajaran lengan metode sugesti-imajinasi. Adapun lagu yang dmilai sesuai dengan pembelajaran menulis desknipsi yang bertemakan pariwisata adalah lagu Yogyakarta.Kutipan syair lagu mi dapat dibagikan kepada siswa.

f. Evaluasi $^{7}$

Buatlah sebuah karangan deskripsi dengan ketentuan sebagal berikut:

7 Svantesson, Ingemar, Learning maps and memory skill: Powerful techniques to help you make better use of your brain, atau Learning maps and memory skill: Teknik-teknik andal untuk memaksimalkan kinerja otak anda, terjemahan Bamban\& Prajoko. (Jakarta: Gramedia 2013) h. 117 
Tema : pariwisata

Sifat : nonfiksi

Panjang karangan minimal 150 kata

Gunakan bahasa Indonesia yang balk dan benar.

3. Tahap Pelaksanaan

Kegiatan pembelajaran dengan metode sugesti-imajinasi dalam pembelajaran menulis dilakukan mengacu pada perencanaan pembelajaran yang sebelumnya telah disusun.

Atas dasar perencanaan itu maka kegiatan guru dan siswa terlihat dalamtabel berikut:

4. Tabel Kegiatan Guru dan Siswa

\section{No Guru}

1) Memberikan soal pretes. soal pretes.

2) Menjelaskan tujuan pembelaaran dan kompetensi dasar yang hendak dicapai.

3) Menjelaskan hubungan materi yang telah dibelajkan dengan materi yang akan dibelajarkan.

4) Menjelaskan praktik pembelajaran dengan media lagu.

5) Membagikan kutipan syair lagu syair lagu.

6) Menyampaikan beberapa hal pentig tentang eara mengeksploitasi lagu an mengolah emosi siswa.

7) Memutar lagu lagu dan menulis gagasan yang muneul.

8) Tanya-jawab tentang cara menelaah dan cara menelaah mengelompokkan gagasan yang dicatat mengelompokkan gagasan yang dicatat.

9) Tanya-jawab tentang cara menyusun cara kerangka

10) Kerangka menyusun karangan yang baik

11) Membantu siswa yang mengalami kesulitan deskripsi dengan tema

\section{Siswa}

Mengerjakan

Menyimak

Menyimak

Menyimak

Membaca

Menyimak

Menikmati

Tanya-jawab

dan

Tanya-jawal

karangan yang baik.

Menyusun karangan 
pariwisata.

12) Mengawastdan memotivasi siswa kripsi yang disusun teman

13) Memberikan soal pascates

Menyunting karangan des

Mengerjakan soal pascates

Kegiatan pembelajaran yang dilakukan guru dan siswa merupakan proses pembelajaran yang berkesinambungan dan padu. Kegiatan guru dan siswa sating mendukung dan mempengaruhi tingkat keberhasilan pembelajaran. Ketidakberhasilan suatu kegiatan berarti berpengaruh bagi ketidakberbasilan kegiatan yang lain. Ketidakberhasilan dalam proses pembelajaran itu pada akhirnya akan bermuara pada tidak tercapainya tujuan pembelajaran.

Sebab itu, guru harus bisa menjadi moderator, motivator, dan fasilitator yang baik dalam kegiatan pembelajaran dengan metode sugesti-imajinasi. Sebagai moderator, guru hendaknya mampu memandu siswa sehingga setiap kegiatan pembelajaran dapat mencapai sasarannya. Kemampuan untuk memotivasi siswa sangat dibutuhkan terutama untuk membangkitkan minat siswa terhadap kegiatan pembelajaran dengan metode sugesti-imajinasi dan media lagu. Kesiapan dan kesediaan guru untuk menjadi fasilitator menjadi kunci penentu keberhasilan kegiatan pembelajaran menulis dengan metode sugesti-imajinasi.Pemahaman dan pendekatan intern dengan siswa menibuka peluang besar bagi terciptanya kegiatan pembelajaran yang sinergis.

\section{Evaluasi}

Evaluasi pada hakekatnya dilakukan selama proses pembelajaran berlangsung, mulai dan pretes pada awal pembelajaran dan pascates pada akhir pembelajaran. Hasil evaluasi dalam contoh penerapan metode sugesti-imajinasi dalam Menulis Deskripsi terlihat seperti dalam tabel berikut:

6. Tabel Evaluasi Proses Pembelajaran

\section{No Respon Siswa}

$\%$

1. Mengerjakan,soaltes 100

2. Bertanya tentang tujuan pembelajaran dan kompetensi dasar 75 yang akan dicapai.

3. Bertanya tentañg hubungan materi yang telah dibelajarkan dengan rnatei yang alum dibelajarkan.

4. Bertanya tentang praktik pembelajaran dengan media lagu.

5. Mengaku menyukai lagu yang dipiib sebagai media pembelajaran.

6. Bertanya tentang lagu yang dipilih sebagai media.

7. Piling yg muncul saat meikmati lagu dan 100 sesudahnya.

8. Aktifdalam kegiatan tanyajawab. 80

9. Membuat telaah dan pengelompokkan gagasan. 100

10. Menyalin kerangka karangan.

Metode Sugesti.... Nursyaidah 
11. Menyusun karangan deskripsi.

100

12. Mengerjakan soal pasca tes

100 dimaksud.

Adapun persentase peningkatan elemen-elemen keterampilan berbahasa yang

a. Hampir semua siswa mengalami peningkatan penguasaan kosakata.

b. Lebih dan 75 persen siswa menjadi lebih mampu menyusun kalimat dengan pola yang benar.

c. Sekitar 70 persen siswa mampu menulis karangan dengan gaya penulisan yang jauh lebih baik.

d. Setelah pembelajaran dengan metode sugesti-imajinasi, 90 persen siswa dapat menulis karangan desknipsi dengan balk.

Ada empat faktor yang memberikan kontribusi bagi peningkatan kualitas pembelajaran menulis dengan metode sugesti-imajinasi ${ }^{8}$.

Pertama, pemilihan lagu yang bersyair puitis membantu para siswa memperoleh model dalam pembelajaran kosakata Pengembangan kosakata yang dimaksud di sini mengandung pengertian lebih dan sekadar penambahan kosakata barn, tetapi lebih pada penempatan konsep-konsep baru dalam tatanan yang lebih balk atau ke dalam susunansusunan tambahan.

Kedua, pembenian apersepsi tentang keterampilan mikrobahasa yang dilanjutkan dengan pembelajaran menulis menggunakan metode sugestiimajinasi dapat diserap dan dipahami dengan lebih baik oleh pars siswa. Situasi emosional yang terolab membantu keberhasilan komunikasi dan interaksi guru dengan siswa. Keberhasilan komunikasi tersebut tercermin pada meningkatnya kemampuan siswa dalam memahami konsepkonsep dan teknik menulis yang disampaikan guru.

Ketiga, sugesti yang diberikan melalul pemutaran lagu merangsang dan mengkondisikan siswa sedemikian rupa sehingga siswa dapat membenikan respons spontan yang bersifat positif. Dalam hal mi, respons yang diharapkan muncul dan pars siswa berupa kemampuan menggali pengalaman hidup atau mengingat kembali faktakta yang pernah mereka temul, mengorganisasikannya, dan membenikan tanggapan berupa ide-ide atau konsep-konsep barn mengenal pengalaman atau fakta-tkta tertentu. Metode sugesti-hnajinasi memungkinkan proses dapat berlangsung dengan baik sehingga pars siswa memiliki cukup baban untuk menulis sebuah karangan deskripsi.

Keempat, peningkatan penguasaan kosakata, pemahaman konsep-konsep dan teknik menulis, serta imajinasi yang terbangun baik berkorelasi dengan peningkatan kemampuan siswa dalam membuat variasi kalimat. Kemampuan membuat vaniasi kalimat itulah yang menjadi tolok ukur kemampuan siswa dalam menemukan gaya penulisan yang baik.

${ }^{8}$ Citrobroto, R.I Suhartin, Teknik belajar yang efektif,(Jakarta: Bhratara Karya Aksara, 2000) h. 88

Metode Sugesti. Nursyaidah 
Selain empat faktor yang menjadikan metode sugesti-imajinasi efektif diterapkan dalam pembelajaran menulis, analisis basil pretes dan pasca tes juga mengidentifikasi adanya kelemahan-kelemahan dan metode sugestiimajinasi.

Pertama, penggunaan metode sugesti-imajinasi tidak cukup efektifbagikelompok siswa dengan tingkat keterampilan menyimak yang rendah.Stimulusyang disampaikan secara lisan menghendaki adanya keterampilan menyimak yang baik.Dengan demikian, komunikasi yang terjalin bisa diarahkan menujutarget yang hendak dicapal, yaitu sugesti untuk membangun imajinasi siswa.

Kedua, metode ini sulit digunakan bila siswa cenderung pasif. MetodesugestiimajInasi merupakan syarat adanya keaktifan dan pihak siswa Siswa harus aktif menerima stimulus dan memberikan respons dalam bentuk simbol-simbol verbal.

Kedua faktor inilah yang menyebabkan 4 siswa (10\%) yang digambarkan pada tabel tidak memperoleh hasil yang optimal. Mereka hanya mémperoleh sedikit peningkatan penguasaan kosakata. Evaluasi proes pembelajaran menguatkan asumsi tersebut. Siswa yang tidak berhasil dalam pembelajaran menulis dengan metode sugestiimajinasi merupakan kelompok siswa yang tidak terlibat aktif dalam proses pembelajaran. Tes menyimak yang dilaksanakan sebelum pelaksanaan remedial menunjukkan bahwa keterampilan siswa tersebut berada di bawah rata-rata siswa kelas itu. Untuk siswa dengan keterampilan menyimak rendah, pembelajaran menulis dengan metode sugesti-imajinasi dapat dikombinasikan dengan pemberian pertanyaanpertanyaan pemandu. Pertanyaan-pertanyaan pemandu itu harus bérkaitan langsung dengan topik karangan. Tujuaanya, untuk membantu siswa dalam menggali pengalaman hidup, mengorganisasikannya, dan akhirnya membenikan respons. Proses tersebut tidak dapat mereka jalani hanya dengan stimulus-stimulus sugesti secara lisan.

\section{PENUTUP}

Berdasarkan analisis proses dan hasil penerapan metode sugesti-imajinasi dalam pembelajaran menulis diperoleh kesimpulan sebagai berikut.

Pertama, lagu dapat menjadi media yang efektif dalam pembelajaran menulis. Efektivitas lagu sebagai media dimaksimalkan dengan prinsip linkand match (hubungan dan kesesuaian). Kedua, imajinasi memberikan kontribusi yang cukup besar pada keberhasilan pembelajaran menulis. Imajinasi yang terbangun baik membantu siswa dalam menggali pengalaman hidup, mengorganisasikannya, dan memberikan respons dalàm bentuk simbol-simbol verbal yang baik. Ketiga, sugesti dapat digunakan untuk merangsang perkembangan imajiasi siswa. Lagu yang digunakan sebagai media pembelajaran menulis dieksploitasi untuk memberikan sugesti kepada siswa. Cara pembelajaran inilah yang disebut dengan metode sugesti-imajinasi. Keempat, metode sugesti-imajinasi dapat meningkatkan keberhasilan pembelajaran menulis pada sekelompok siswa dengan tingkat keterampilan menyimak yang baik dan siswa yang aktif. Keterampilan menyimak yang baik dan keaktifan siswa menjadi prasyarat dalam penerapan metode sugesti-imajinasi. Agar metode sugesti-imajinasi ini dapat berhasil 
dengan baik disarankan sebagai berikut Pertama, karena pentingnya, pembelajaran menulis hendaknya selalu menggunakan media. Pemilihan media hendaknya disesuaikan dengan materi, metode, dan kondisi para siswa. Kedua, Pengembangan imajinasi hendaknya mendapat porsi yang cukup dalain pembelajaran bahasa dan sastra. Imajinasi yang merupakan daya pikir untuk membayangkan atau menciptakan gambaran-gambaran akan sangat membantu siswa dalam menentukan pilihan-pilihan hidup dan mengantisipasi setiap masalah yang akan mereka hadapi di masa depan.

\section{DAFTAR PUSTAKA}

Ali, Lukman, dkk. Kamus besar bahasa Indonesia. Jakarta: Balai Pustaka, 1990

Citrobroto, R.I. Suharti. Teknik belajar yang efektif. Jakarta: Bhratara Karya Aksara, 1981

De Porter, Bobbi and Mike Hernacki, Quantum learning: Unleashing the genius in you, atau Quantum learning: Membiasakan belajar nyaman dan menyenangkan, teijemahan Alwiyah Abdurrabman. Bandung: Kaifa, 1999.

Ginting,Vera, Penguatan Membaca, fasilitas sekolah dan keterampilan dasar membaca serta minat baca murid. artikel dalam Jurnal Pendidikan Penabur, No.O4fIV/Juli 2005.

Keraf, Gorys, Komposisi: Sebuah pengantar kemahiran bahasa. Flores: Nusa Indah, 1994

Rabman, H, Eksploitasi potensi gambar dalam meningkatkan kemampuan menulis kalimat. Bandung: Ikatan Alumni FPBS dan Prodi Pengajaran Bahasa Indonesia Program Pascasarjana UPI (makalah, tidak diterbitkan), 2005

Svantesson, Ingemar, Learning maps and memory skill: Powerful techniques to help you make better use of your brain, atau Learning maps and memory skill: Teknik-teknik andal untuk memaksimalkan kinerja otak anda, terjemahan Bambang Prajoko. (Jakarta: Gramedia. 2005

Tarigan, Henry Guntur, Pengajaran kosakata. Bandung: Angkasa, 1985 